\title{
Effect of Anadenathera macrocarpa (Benth) Brenan extracts in tomato, pepper and corn seedlings
}

\section{Efeito de extratos de Anadenathera macrocarpa (Benth) Brenan em plântulas de tomate, pimentão e milho}

\author{
Luciana Barboza SILVA ${ }^{1}$; Glauciany Soares LOPES ${ }^{2}$; Eliane CARNEIRO ${ }^{3}$; Sammy Nery de SOUSA ${ }^{1}$; \\ Manoel Lopes da SILVA FILHO'; Fernandes Antônio ALMEIDA ${ }^{4}$ \\ ${ }^{1}$ Doutor(a), professor(a) da Universidade Federal do Piauí, Bom Jesus, PI, Brasil. E-mail: lubarbosabio@hotmail.com; \\ sammynery@ufpi.edu.br; manoellopes@ufpi.edu.br \\ ${ }^{2}$ Mestre, Universidade Federal do Piauí, Bom Jesus, PI, Brasil. E-mail: glaucianylopes@gmail.com \\ ${ }^{3}$ Autor para correspondência" Doutoranda no Programa de Pós-graduação em Agronomia da Universidade Tecnológica Federal \\ do Paraná, Pato Branco, PR, Brasil. E-mail: elian.cbs@hotmail.com \\ ${ }^{4}$ Doutor, professor da Universidade Federal de Campina Grande, Pombal, PB, Brasil; Email: fernandesalmei@gmail.com
}

Recebido em: 04-08-2020; Aceito em: 28-10-2020

\begin{abstract}
The objective was to study the effect of ethanolic extracts of the leaves and bark of Anadenathera macrocarpa (angico-preto) on the germination and development of tomato, pepper and maize seedlings. For the bioassays, concentrations of $0,250,500$ and $1,000 \mathrm{mg} \mathrm{mL}^{-1}$ were used. Fifty seeds of each plant species were used to evaluate daily germination and ten seedlings were used to evaluate growth. The primary root growth of the maize was stimulated by the $250 \mathrm{mg} \mathrm{mL}^{-1}$ concentration of the leaf extract and in the presence of the bark extract the growth was linear. The germination speed index and germination percentage increased when using the concentrations of 615.8 and $724.4 \mathrm{mg} \mathrm{mL}^{-1}$, respectively. The concentration of $654.9 \mathrm{mg} \mathrm{mL}^{-1}$ increased the hypocotyl length and that of $628.1 \mathrm{mg} \mathrm{mL}^{-1}$ increased the radicle length of pepper. The length of the tomato radicle was influenced by the concentrations; it was shorter as the concentration increased. Therefore, despite acting differently in each species, A. macrocarpa leaf and bark extracts interfere with the germination and growth of the tested crops.
\end{abstract}

Additional keywords: Angico-preto; Capsicum annuum; secondary metabolites; Solanum lycopersicum; Zea mays

\section{Resumo}

O objetivo foi estudar o efeito de extratos etanólicos das folhas e da casca de Anadenathera macrocarpa (angico-preto) na germinação e desenvolvimento de plântulas de tomate, pimentão e milho. Para os bioensaios, foram utilizadas concentrações de $0,250,500$ e $1.000 \mathrm{mg} \mathrm{mL}^{-1}$. Cinquenta sementes de cada espécie de planta foram utilizadas para avaliar a germinação diária e dez plântulas foram utilizadas para avaliar o crescimento. $\mathrm{O}$ crescimento da raiz primária do milho foi estimulado pela concentração de $250 \mathrm{mg} \mathrm{mL}^{-1}$ do extrato da folha e na presença do extrato da casca o crescimento foi linear. $O$ índice de velocidade de germinação e o percentual de germinação aumentaram com as concentrações de 615,8 e $724,4 \mathrm{mg} \mathrm{mL}^{-1}$, respectivamente. A concentração de $654,9 \mathrm{mg} \mathrm{mL}^{-1}$ aumentou o comprimento do hipocótilo e a de $628,1 \mathrm{mg} \mathrm{mL}^{-1}$ aumentou o comprimento da radícula do pimentão. O comprimento da radícula de tomate foi influenciado pelas concentrações; foi menor com aumento das concentrações. Portanto, apesar de agir diferentemente em cada espécie, os extratos de folhas e cascas de A. macrocarpa interferem na germinação e no crescimento das culturas testadas.

Palavras-chave adicionais: Angico-preto; Capsicum annuum; metabolitos secundários; Solanum lycopersicum; Zea mays.

\section{Introduction}

In the Brazilian Cerrado there are plant species that are popularly reported to contain important bioactive properties with allelopathic potential, mainly to control intra and interspecific species competing within the edaphoclimatic conditions of the ecosystem they occupy. Among these, there is angico-preto (Anadenathera macrocarpa (Benth) Brenan) (Silva et al., 2010), a widely distributed species that occurs from southern Bolivia to northern Argentina, as well as throughout Brazil, except for the South Region (Lorenzi \& Matos, 2002).

Due to its importance in popular medicine, various chemical studies have been conducted on this species in relation to terpenoids, flavonoids, iridoids, benzenoids, polyphenols and alkaloids (Gutierrez-Lugo et al., 2004; Araújo et al., 2008; Weber et al., 2011). In study realized for Gutierrez-Lugo et al. (2004) with aerial parts of angico-preto (Anadenanthera colubrine (Vell.) Brenan) led to the isolation of a new flavonoid named anadanthoflavone, along with 11 known compounds: 
alnusenol, lupenone, lupeol, betulinic acid, alphaamyrin, beta-amyrin, beta-sitosterol, stigmasterol, apigenin, 4-hydroxybenzoic acid and cinnamic acid. The isolated compounds presented inhibition lipoxygenase.

The compounds of the specialized metabolism of plants have diverse functions. In addition to the important physiological roles they play, many are of economic interest to produce pharmaceutical, nutraceutical, flavor, fragrance and pigment products Allelochemical activity has been used as an alternative to herbicides, insecticides and nematicides (pesticides) (Bohlmann \& Keeling, 2008).

These specialized metabolites help protect plants against herbivores and pathogens and attract pollinators and animal seed dispersers (Cheng \& Cheng, 2015). Some plant species are allopathic because they reduce or stimulate seed germination and initial development due to chemical compounds produced and released into the environment (Kruidhof et al., 2011; Bezuidenhout et al., 2012), via volatilization, root exudation, leaching and decomposition of plant tissues (Nóbrega et al., 2009). Thus, investigating allelochemical compounds in leaf and bark extracts of $A$. macrocarpa is an important way to identify new sources of chemical compounds that can be used in phytosanitary management.

The mode of action of secondary metabolites as allelopathic can be specific, that is, tolerance or resistance to allelochemicals varies from species to species, thus, sensitive crops such as lettuce, onion, tomato and cucumber are used as indicators of allelopathic activities (Alves et al., 2004). Therefore, in addition to tomatoes (Solanum lycopersicum), pepper (Capsicum annuum L.) from the Solanaceae family, we also use corn (Zea mays L.) because it is considered a model plant for grasses and for its economic importance (Macias et al., 2000). In this context, the objective was to evaluate the effect of ethanolic extracts of leaves and peels of $A$. macrocarpa in the germination and development of tomato, pepper and corn seedlings.

\section{Material and methods}

\section{Obtaining the extracts}

The extracts were prepared using the leaves and stem bark of $A$. macrocarpa, which were collected in the city of Angical-PI (06 $05^{\prime} 09^{\prime \prime}$, $\left.42^{\circ} 44^{\prime} 20^{\prime \prime} \mathrm{W}\right)$ during August and October 2014. The plant material (specimen no 21.643TEPB) was identified in the Graziela Barroso Herbarium at the Federal University of Piauí, Campus Ministro Petrônio Portela, Teresina-PI.

To prepare the extracts, the bark and leaves were cleaned to remove impurities, leaves that were visibly damaged, insects and other organisms. Soon after, the plant material was pre dried for 72 hours in a forced circulation dryer at $60^{\circ} \mathrm{C}$. The dried material was ground with a knife mill to obtain a powder and put back in the circulation dryer for $72 \mathrm{~h}$ at $60^{\circ} \mathrm{C}$. The material was then weighed with an analytical balance and $1230 \mathrm{~g}$ of the leaves and $450 \mathrm{~g}$ of the bark were used, which were soaked in $1,000 \mathrm{~mL}$ and $500 \mathrm{~mL}$ of absolute ethanol, respectively, for $72 \mathrm{~h}$, next, was put in glass flasks and stirred and evaporated until it reached the consistency of paste, which resulted in $70.71 \mathrm{~g}$ of leaf ethanolic extract and $30.47 \mathrm{~g}$ of bark ethanolic extract.

\section{Allelopathic bioassays}

The experiment had a completely randomized design with eight treatments distributed in a 4x2 factorial scheme, with four concentrations of extracts of two parts of $A$. macrocarpa: leaves and bark. The experimental unit for the germination bioassay was composed of 50 seeds, of pepper, tomato and maize, and the growth measured considered 10 seedlings.

The following commercial seeds were used: tomato (Solanum lycopersicum, Solanaceae), cv. Santa Adélia; pepper (Capsicum annuum L.; Solanaceae), cv. Ikeda; and maize (Zea mays L.; Poaceae), cv. DKB390RK. All of the selected seeds were the same size, shape and color, and were treated with $2 \%$ sodium hypochlorite, washed with distilled water and dried on filter paper (Brasil, 2009).

For the bioassays of the leaves and bark ethanolic extracts of $A$. macrocarpa, the concentrations 0 (control), 250, 500 and 1,000 $\mathrm{mg} \mathrm{mL}^{-1}$ were used; the most concentrated was obtained by weighing and the remaining were obtained by dilution.

For the tomato and pepper seeds, the bioassays were conducted in germination boxes (gerbox) containing filter paper impregnated with $5 \mathrm{~mL}$ of the plant extracts. For the maize seeds, sheets of germitex paper impregnated with $50 \mathrm{~mL}$ of the solution were used. After the ethanol evaporated, the paper was soaked in distilled water and then 50 seeds were randomly distributed in the gerboxes with the filter paper (tomato and pepper) and germitex paper (maize). The experiment was conducted in BOD (Biochemical Oxigen Demand) chambers $\left(25 \pm 2{ }^{\circ} \mathrm{C}\right.$ and $12 \mathrm{~h}$ constant photoperiod) for 10 days, that, when necessary, were watered with distilled water (Brasil, 2009). For the initial growth assessments, the radicle (primary root) and hypocotyl (coleoptile to maize) of 10 seedlings per box were measured with millimeter paper.

For the germination bioassay, the method by Macias et al. (2000) was used, where the germination count was conducted based on the protrusion of the radicle to $2 \mathrm{~mm}$. The parameters evaluated were germination percentage (G) and germination speed index (GSI). The germination count started on the third day after sowing and was conducted daily until the tenth day after sowing. Subsequently, the germination percentage (G) was determined through the equation proposed by Labouriau and Valadares (1976): $\mathrm{G}=(\mathrm{N} / \mathrm{A}) \times 100$, where $\mathrm{G}=$ germination percentage, $\mathrm{N}=$ number of germinated seeds, and $A=$ the number of seeds used. The germination speed index (GSI) was determined using the following formula: $\mathrm{GSI}==\mathrm{G} 1 / \mathrm{N} 1+\mathrm{G} 2 / \mathrm{N} 2+\ldots$ GN/NN, wherein $\mathrm{G} 1, \mathrm{G} 2$ and $\mathrm{GN}$ represent the number of normal seeds germinated until the nth day and N1, $\mathrm{N} 2$ and NN represent the number of days that 
germination was evaluated (Hoffmann et al., 2007; Lima et al., 2011). The experiment was concluded when there was no germination for three consecutive days.

The data were submitted to an analysis of variance. After the preliminary analysis, the results for significant interactions were obtained and a regression analysis was conducted. The averages were compared with Tukey's test at $5 \%$ probability. The analyzes were performed using the System of Statistical Analyzes (SAS) program (SAS Institute, 2002).

\section{Results and discussion}

A significant difference was verified for both radicle and coleoptile length of the maize seedlings when the extracts were used. Among the concentrations, coleoptile length, germination speed index and germination percentage had significant differences. The interaction between the extracts and concentrations was only significant for coleoptile length (Table 1).

Table 1 - Average germination percentage (G), germination speed index (GSI), radicle length (RL) and coleoptile length $(\mathrm{CL})$ of maize treated with ethanolic extracts of the leaves and bark of $A$. macrocarpa at four concentrations.

\begin{tabular}{lcccc}
\hline Source of variation & $\mathrm{G}(\%)$ & $\mathrm{GSI}$ & $\mathrm{RL}(\mathrm{mm})$ & $\mathrm{CL}(\mathrm{mm})$ \\
\hline Extracts (E) & $0.12^{\mathrm{ns}}$ & $0.005^{\mathrm{ns}}$ & $27.91^{* *}$ & $0.91^{* *}$ \\
\hline Leaves & $99.75 \mathrm{a}$ & $23.83 \mathrm{a}$ & $14.988 \mathrm{a}$ & $5.68 \mathrm{~b}$ \\
Bark & $99.62 \mathrm{a}$ & $23.86 \mathrm{a}$ & $13.120 \mathrm{~b}$ & $6.02 \mathrm{a}$ \\
\hline Concentrations (C) & $1.79^{*}$ & $0.507^{*}$ & $2.44^{\mathrm{ns}}$ & $1.76^{* *}$ \\
E x C & $0.12^{\mathrm{ns}}$ & $0.084^{\mathrm{ns}}$ & $3.84^{\mathrm{ns}}$ & $1.01^{* *}$ \\
\hline CV (\%) & 0.68 & 1.40 & 9.28 & 4.88
\end{tabular}

${ }^{* *}$ significant at $1 \%$ by F test; * significant at $5 \%$ by F test; ${ }^{\text {ns }}$ not significant by $\mathrm{F}$ test. CV - coefficient of variation. Averages followed by the same letter in a column do not differ significantly based on Tukey's test at $5 \%$ probability.

Germination is a complex process during which the mature seed resumes growth and shifts from a maturation- to germination-driven programme of development (Wolny et al., 2018), the germination initiates when water enters the embryo and ends with the protrusion of the radicle; the water needs to enter quickly due to the large difference in water potential between the seed and environment (Finch-Savage \& Leubner-Metzger, 2006). Frequently, germination percentage does not suffer from the allelopathic effects of extracts, unlike germination speed and other parameters (e.g., primary root length) where the effects are more evident (Carvalho et al., 2015).

The effect of the leaves and bark ethanolic extracts of $A$. macrocarpa did not metabolically influence the germination processes of the tomato seeds. However, the effect of the extracts was different for the maize seeds, which were stimulated at low concentrations and suppressed as the concentration increased. The concentration had a negative effect on the pepper seeds; germination decreased as the concentration increased. This variation can occur because of compounds in plants that act differently based on the environment and life cycle stage of the target plant; the effects might also vary based on the plant organ (Santos et al., 2015). This is supported by the germination analysis of the tomato, maize and pepper, since the ethanolic extracts of the bark and leaves behaved differently for each species.
When comparing the concentrations used, that the coleoptile length was linear as the concentration of the bark extract increases; for this, the effects of leaves extract was similar to the control (Figure 1).

The concentration of $615.8 \mathrm{mg} \mathrm{mL}^{-1}$ of the extracts (independent of the source - leaves and bark), estimated using the equation $Y=23.5654+0.0017 X$ - $1.3803 E-6 X^{2}\left(R^{2}=0,68\right)$, increased the germination speed index by $5.5 \%$ compared to the control. According to the regression analysis conducted, the $724.4 \mathrm{mg} \mathrm{mL}^{-1}$ concentration increased germination compared to the control. However, a decrease in both the germination speed index and germination percentage might occur for concentrations greater than those indicated above.

The maize, pepper and tomato seedlings were affected by the presence of the extracts at the different concentrations. Coleoptile growth of the maize seedlings was significantly influence by the $A$. macrocarpa bark extract, increasing linearly with increasing concentrations, but the leaf extract did not affect its development.

There were significant differences for the hypocotyl and radical length parameters of the pepper seedlings, using the bark and leaves extracts of A. macrocarpa, as well as for the concentrations used (Table 2). The concentrations of the leaves and bark ethanolic extracts did not interfere with the germination speed index or germination percentage of the pepper seeds (Table 2). 


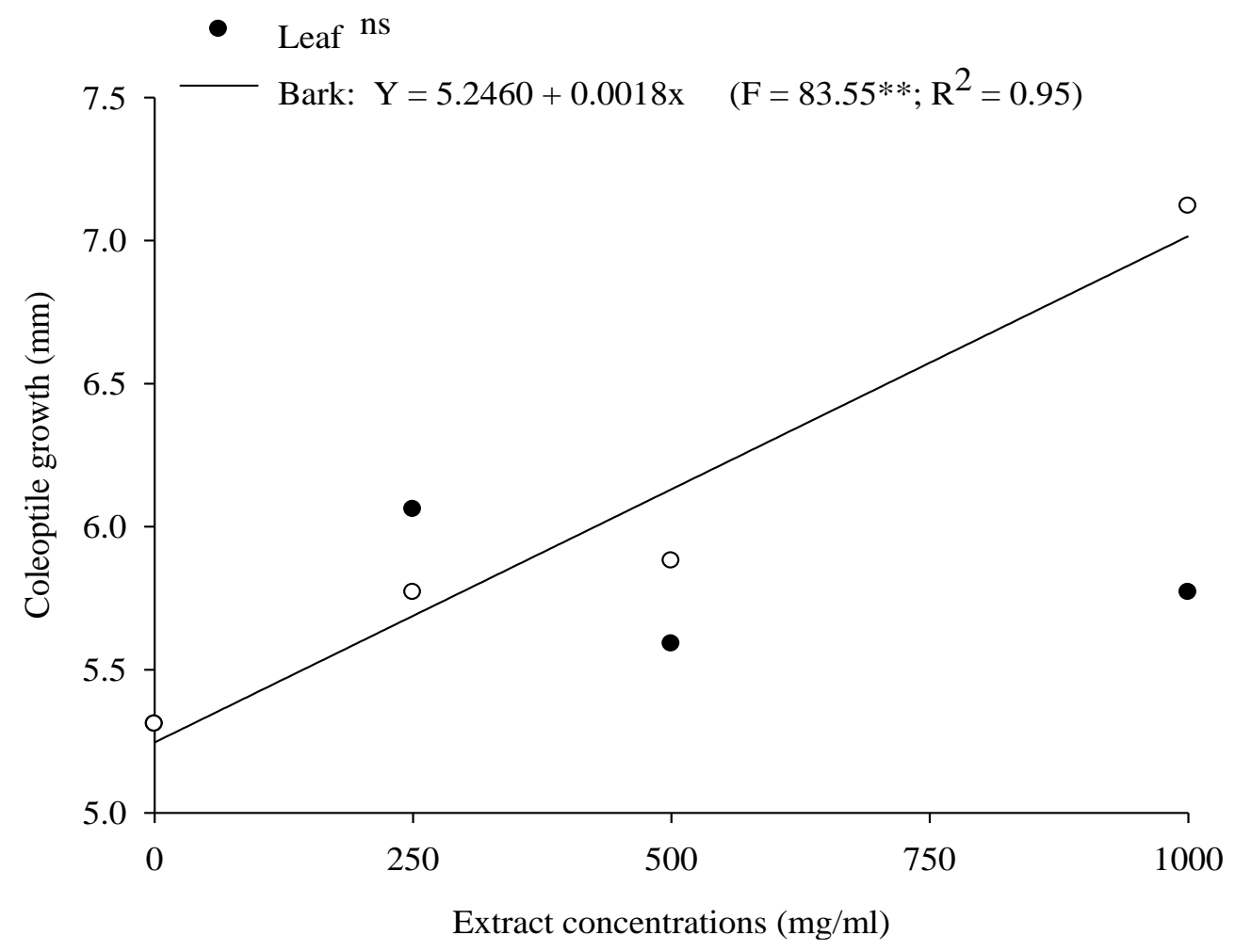

Figure 1 - Average coleoptile length of maize submitted to concentrations of ethanolic extracts of the bark and leaves of $A$. macrocarpa.

Table 2 - Average germination percentage $(G)$, germination speed index (GSI), radicle length (RL) and hypocotyl length (HL) of pepper treated with ethanolic extracts of the bark and leaves of $A$. macrocarpa at four concentrations.

\begin{tabular}{lcccc}
\hline Source of variation & $\mathrm{P}(\%)$ & $\mathrm{GSI}$ & $\mathrm{RL}(\mathrm{mm})$ & $\mathrm{HL}(\mathrm{mm})$ \\
\hline Extracts $(\mathrm{E})$ & $2^{\mathrm{ns}}$ & $0.0357^{\mathrm{ns}}$ & $8.64^{*}$ & $9.25^{*}$ \\
\hline Leaves & $96.50 \mathrm{a}$ & $10.26 \mathrm{a}$ & $11.55 \mathrm{a}$ & $9.50 \mathrm{a}$ \\
Bark & $96.00 \mathrm{a}$ & $10.19 \mathrm{a}$ & $10.51 \mathrm{~b}$ & $8.42 \mathrm{~b}$ \\
\hline Concentrations (C) & $21^{\mathrm{ns}}$ & $0.3833^{\mathrm{ns}}$ & $11.90^{* *}$ & $11.04^{* *}$ \\
E x C & $8.33^{\mathrm{ns}}$ & $0.0077^{\mathrm{ns}}$ & $2.21^{\mathrm{ns}}$ & $2.77^{\mathrm{ns}}$ \\
\hline CV $(\%)$ & 2.97 & 4.57 & 12,42 & 13.73 \\
\hline
\end{tabular}

${ }^{* *}$ significant at $1 \%$ by F test; *significant at $5 \%$ by F test; ${ }^{\text {ns }}$ not significant by $\mathrm{F}$ test. CV - coefficient of variation. Averages followed by the same letter in a column do not differ significantly based on Tukey's test at $5 \%$ probability.

The interaction between the concentrations and extract only had a significant effect for the germination speed index (Table 2).

The concentration associated with the greatest hypocotyl length (26\% longer than the control) of the pepper seedlings was estimated to be $654.9 \mathrm{mg} \mathrm{mL}^{-1}$ (Figure 2). For the greatest radicle length (31\% greater than the control), the estimated concentration was $628.1 \mathrm{mg} \mathrm{mL}^{-1}$ (Figure 3). However, note that an increase in the concentration can lead to a decrease in radicle length and hypocotyl length (Figures 2,3).

Based on the results of Table 3, no significant differences were observed for the extracts used and the parameters evaluated. Note that only the radicle length variable was significantly different. However, no significant difference was observed for the evaluated parameters when comparing the interaction between the extract and concentrations used. 




Figure 2 - Hypocotyl length $(\mathrm{mm})$ of pepper seedlings in function of concentrations of the ethanolic extract of $A$. macrocarpa.

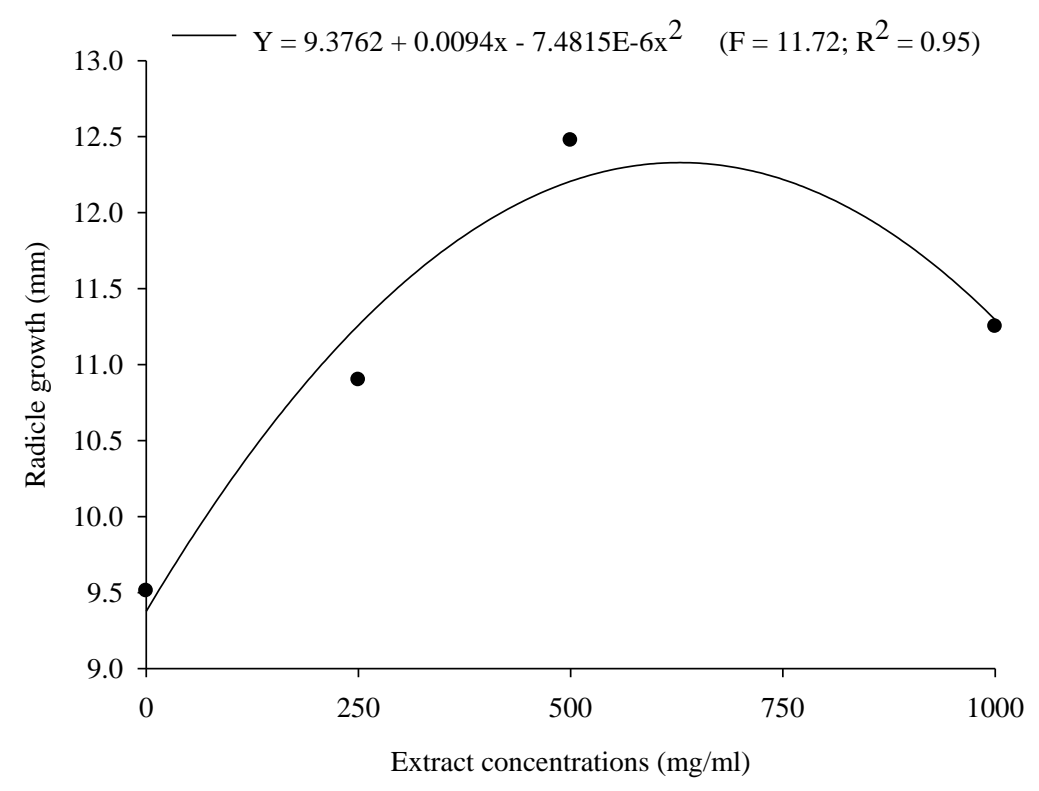

Figure 3 - Radicle length $(\mathrm{mm})$ of pepper seedlings in function of concentrations of the ethanolic extract of $A$. macrocarpa.

Table 3 - Average germination percentage $(G)$, germination speed index (GSI), radicle length $(R L)$ and hypocotyl length $(\mathrm{HL})$ of tomato treated with ethanolic extracts of the leaves and bark of $A$. macrocarpa at four concentrations.

\begin{tabular}{lcccc}
\hline Source of variation & $\mathrm{G}$ & $\mathrm{GSI}$ & $\mathrm{RL}(\mathrm{mm})$ & $\mathrm{HL}(\mathrm{mm})$ \\
\hline Extracts $(\mathrm{E})$ & $3.12^{\mathrm{ns}}$ & $1.03^{\text {ns }}$ & $0.68^{\mathrm{ns}}$ & $0.25^{\mathrm{ns}}$ \\
\hline Leaves & $95.25 \mathrm{a}$ & $10.83 \mathrm{a}$ & $3.29 \mathrm{a}$ & $1.67 \mathrm{a}$ \\
Bark & $95.87 \mathrm{a}$ & $11.19 \mathrm{a}$ & $3.59 \mathrm{a}$ & $1.85 \mathrm{a}$ \\
\hline Concentrations $(\mathrm{C})$ & $8.79^{\mathrm{ns}}$ & $0.42^{\mathrm{ns}}$ & $2.08^{\text {** }}$ & $0.08^{\mathrm{ns}}$ \\
$(\mathrm{E}) \times(\mathrm{C})$ & $4.45^{\mathrm{ns}}$ & $0.74^{\mathrm{ns}}$ & $0.09^{\mathrm{ns}}$ & $0.03^{\mathrm{ns}}$ \\
\hline $\mathrm{CV}(\%)$ & $3,33^{\circ}$ & 4.83 & 14.96 & 23.46 \\
\hline
\end{tabular}

${ }^{* *}$ significant at $1 \%$ by $\mathrm{F}$ test; ${ }^{*}$ significant at $5 \%$ by $\mathrm{F}$ test; ${ }^{\text {ns }}$ not significant by $\mathrm{F}$ test. $\mathrm{CV}$ - coefficient of variation. Averages followed by the same letter in a column do not differ significantly based on Tukey's test at $5 \%$ probability. 
The radicle length of the tomato seedlings decreased as the concentration increased. For the
$1.000 \mathrm{mg} \mathrm{mL}^{-1}$ concentration, there was a $71 \%$ reduction in growth compared to the control (Figure 4).

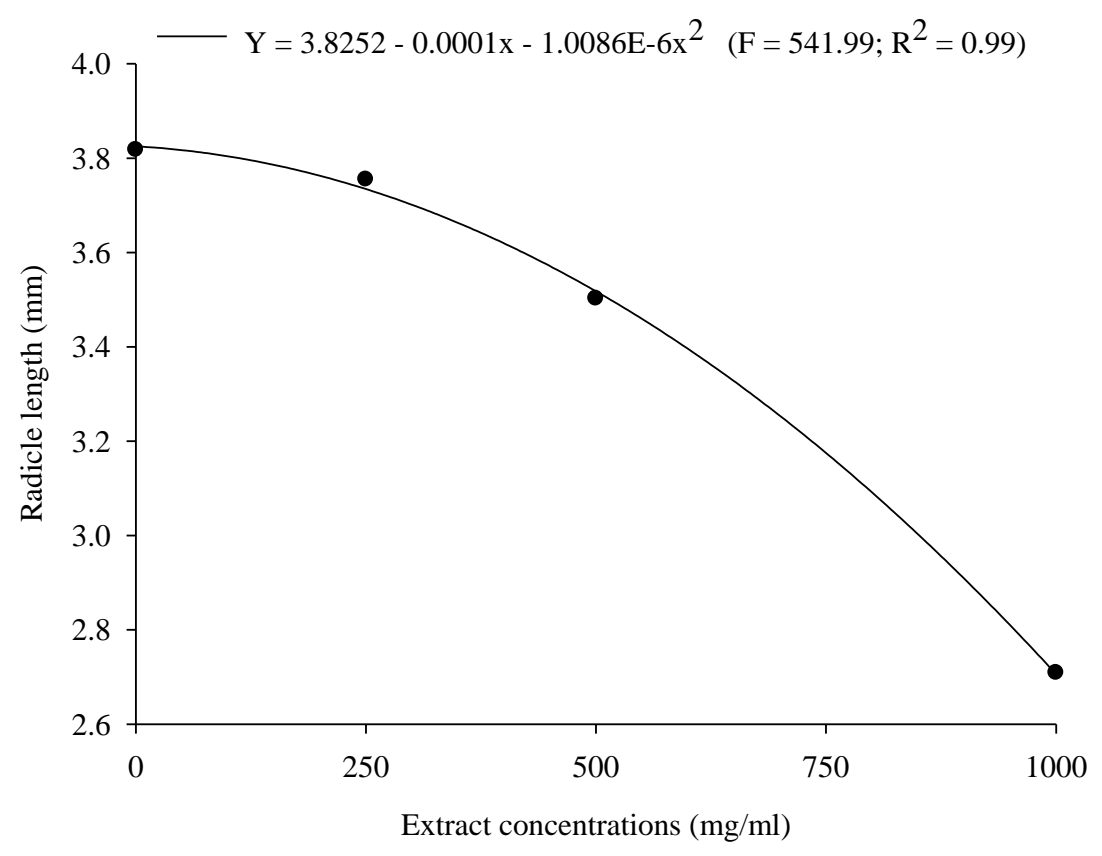

Figure 4 - Radicle length $(\mathrm{mm})$ of the tomato in function of the concentrations of the ethanolic extract of $A$. macrocarpa.

The results obtained showed a marked reduction in the radicle and GSI length, which decreased with increasing concentrations used. These results suggest the presence of secondary metabolites with allelopathic effect in the A. macrocarpa extract because, according to Roze et al. (2011), allelopathic substances are intermediary or final products of the secondary metabolism of plants. Cheng \& Cheng (2015) suggest that these substances can be exuded from various plant parts (mostly the leaves and roots) into the soil, where they combine in many ways and can strongly interfere with the metabolism of other organisms.

The effects of allelochemicals on the radicular system are more severe as contact with the allelochemical solution increases and, at this stage, the deleterious effects on the metabolism are more drastic, since the radicular system is the primary target of the secondary metabolisms, allied to the high radicular metabolism and sensitivity to environmental stress (Reigosa et al., 2013).

Allelochemical substances act directly on the physiology of plants, especially the division, elongation and structure of cells and also, influence growth, cell membrane permeability, respiration, photosynthesis, and lipid, protein and fatty acid synthesis (Ferreira et al., 2008). The presence of these metabolites in the leaves and bark extracts of $A$. macrocarpa could have interfered with some of these physiological processes, causing the effects observed, such as increased coleoptile growth of the maize seedlings and inhibiting the growth of the pepper roots.
According to the results of Monteiro et al. (2006), representatives of the same genus as A. macrocarpa have important phenolic groups used in plant defense, of which tannins are the most diverse. Gutierrez-Luzo et al. (2004) and Weber et al. (2011) report that Anadenanthera colubrina (synonym of $A$. macrocarpa) has medicinal properties due to the presence of bioactive compounds, such as triterpenes, sterols, polysaccharides, and phenolic compounds (e.g., flavonoids, pphenols, and tannins). The main substances cited as having allelopathic potential are benzoquinones, coumarins, flavonoids, lignin, terpenoids, lactones, mucilage, tannins and alkaloids (Vyvyan, 2002; Santos et al., 2011). Thus, the results suggest the presence of these allelochemicals in the ethanolic extracts of the leaves and bark of $A$. macrocarpa used in this study.

A contrast was verified between the effects caused by the $A$. macrocarpa leaves and bark extracts on the species studied. It was also discovered that the same extract had different results between different parts of the plant in the same species. Rosa et al. (2013) also found a contrast for radicle length of radish when using leaf and bark extracts of Salix smithiana, proving that different parts of the same plant species can exhibit different allelopathic effects when different extracts are used, such as promoting or inhibiting radicular growth and development.

The effects of allelochemicals depend on the concentration and amount available for absorption (Silva \& Silva, 2007). Allelopathic compounds act dif- 
ferently on plant species. Some species are more sensitive than others, for example, lettuce and tomato, which are commonly used in laboratory biotests. However, in some cases, it is not possible to determine the crop that is most sensitive to extracts, as found by Gusman et al. (2011) who tested aqueous extracts of Bidens pilosa, Euphorbia heterophylla and Cyperus rotundus leaves on the germination and growth of lettuce, tomato and radish.

There is evidence that one mechanism of action of phenolic compounds is to change the level of indoleacetic acid (IAA), although other substances (e.g., scopoletin and chlorogenic, cinnamic and benzoic acid) inhibit or stimulate the level of IAA (Grossmann, 2010). Phenolic acids can be divided into IAA suppressors (e.g., chlorogenic, caffeic and ferulic acid) and IAA stimulants (e.g., p-coumaric, p-hydroxybenzoic and vanillic acid) (Spilioti et al., 2014), which can explain the effects caused by the $A$. macrocarpa extracts on the maize, pepper and tomato species since, as mentioned, studies of the same genus as $A$. macrocarpa report the presence of phenolic compounds in plant structures.

In addition, some polyphenols reduce seedling growth by binding to gibberellic acid (GA) and others promote growth by binding to abscisic acid (ABA) (Pires \& Oliveira, 2011). Bai et al. (2016), in a bioassay with peas and cucumbers, observed that tannins inhibited the growth of plants induced by $\mathrm{GA}$.

\section{Conclusions}

The extracts of leaves and bark of $A$. macrocarpa interfere with the germination and growth of corn, peppers and tomatoes.

\section{Acknowledgments}

The authors would like to thank the Fundação Amparo a Pesquisa do Piauí - FAPEPI and the Coordenação de Aperfeiçoamento de Pessoal de Nível Superior - Brasil (CAPES) Finance Code 001". The Federal University of Piauí, for its structure and support in conducting the research.

\section{References}

Alves MDCS, Medeiros Filho S, Innecco R, Torres SB (2004) Alelopatia de extratos voláteis na germinação de sementes e no comprimento da raiz de alface. Pesquisa agropecuária brasileira 39(11)1083-1086.

Araújo TAS, Alencar NL, Amorim ELC, Albuquerque UP (2008) A new approach to study medicinal plants with tannins and flavonoids contents from the local knowledge. Journal of Ethnopharmacology 120(1):7280.

Bai L, Deng H, Zhang X, Yu X, Li Y (2016) Reinhardt Gibberellin Is Involved in Inhibition of Cucumber Growth and Nitrogen Uptake at Suboptimal Root-Zone Temperatures. PLoS One 11(5):e0156188.
Bezuidenhout SR, Reinhardt CF, Whitwell MI (2012) Cover crops of oats stooling rye and three annual ryegrass cultivars influence maize and Cyperus esculentus growth Weed. Research Journal 52(1): 153-160.

Bohlmann J, Keeling CI (2008) Terpenoid biomaterials. Plant Journal 54(4):656-669.

Brasil Ministério da Agricultura Pecuária e Abastecimento (2009) Regras para análise de sementes/Ministério da Agricultura Pecuária e Abastecimento Secretaria de Defesa Agropecuária - Brasília: Mapa/ACS. Disponível em < https://www.abrates.org.br/files/regras analise de se mentes.pdf> Acesso em 10 mar. 2015

Carvalho FP, Melo CAD, Machado MS, Dias DCFS, Alvarenga EM (2015) The allelopathic effect of eucalyptus leaf extract on grass forage seed. Planta Daninha 33(2):193-201.

Cheng F, Cheng Z (2015) Research progress on the use of plant allelopathy in agriculture and the physiological and ecological mechanisms of allelopathy. Front Plant Science 6(1):1-16.

Ferreira NR, Medeiros RB, Soares GLG (2008) Alelopathic potential of capim-annoni-2 (Eragrsotis plana Nees) on the seed germination of summer perennial grasses. Revista Brasileira de Sementes 30(2): 043-050.

Finch-Savage WE, Leubner-Metzger G (2006) Seed dormancy and control of germination Tansley. Review New Phytologist 171:501-523.

Grossmann K (2010) Auxin herbicides: current status of mechanism and mode of action. Pest Management Science 66(2):113-120.

Gusman GS, Yamagushi QM, Vestena S (2011) Potencial alelopático de extratos aquoso de Bidens pilosa $\mathrm{L}$ Cyperus rotundus $\mathrm{L}$ e Euphorbia heterophylla $L$. Inheringia Série Botânica 66(1):87-98.

Gutierrez-Lugo MT, Deschamps JD, Holman TR, Suarez E, Timmermann BN (2004) Lipoxygenase inhibition by anadanthoflavone a new flavonoid from the aerial parts of Anadenanthera colubrine. Planta Medica 70(3):263-265.

Hoffmann CEF, Neves LAD, Bastos CF, Wallau GL (2007) Atividade alelopática de Nerium oleander L. e Dieffenbachia picta Schott em sementes de Lactuca sativa L. e Bidens pilosa L. Revista de Ciências Agroveterinária 26(1):11-21.

Kruidhof HM, Gallandt ER, Haramoto ER, Bastiaans L (2011) Selective weed suppression by cover crop residues: effect of seed mass and timing of species sensitivity. Weed Research Journal 51(2):177-186. 
Labouriau LG, Valadares MB (1976) On the germination of seeds of Calotropis procera. Anais da Academia Brasileira de Ciências 48(2):174-186.

Lima CR, Pacheco MV, Bruno RSA, Ferrari CS, Braga Júnior CM, Bezerra AKD (2011) Temperaturas e substratos na germinação de sementes de Caesalpinia pyramidalis TUL. Revista Brasileira de Sementes 33(2):216-222.

Lorenzi H, Matos FJA (2002) Plantas Medicinais no Brasil: nativas e exóticas. Instituto Plantarum de Estudos da Flora, São Paulo. 542p.

Macias FA, Castellano D, Molinillo JM (2000) Search for a standart phytotoxic bioassay for allelochemicals Selection of standard target species. Journal of Agricultural and Food Chemistry 48(6):2512-2521.

Monteiro JM, Almeida CFCBR, Albuquerque UP, Lucena RFP, Florentino ATN, Oliveira RLC (2006) Use traditional management of Anadenanthera colubrina (Vell) Brenan in the semi-arid region of northeastern Brazil. Journal of Ethnobiology and Ethnomedcine 2(1):1-7.

Nóbrega LHP, Lima GP, Martins GI, Meneghetti AM (2009) Germinação de sementes e crescimento de plântulas de soja (Glycine max L Merrill) sob cobertura vegetal $L$ Merrill) sob cobertura vegetal. Acta Scientiarum Agronomy 31(3):461-465.

Pires NM, Oliveira VR (2011) Alelopatia In: Oliveira Junior RS, Constantin J, Inoue MH (Eds) Biologia e Manejo de Plantas Daninhas. Omnipax, Curitiba. 123p.

Reigosa M, Gomes AS, Ferreira AG, Borghetti F (2013) Allelopathic research in Brazil. Acta Botanica Brasilica 27(4):629-646

Rosa JM, Mea LGWD, Agostinetto L, Boff MIC (2013) Efeito alelopático de Salix spp. sobre a germinação de sementes e desenvolvimento de plântulas de Raphanus sativus. Revista de Ciências Agroveterinárias 12(3):255-263.

Roze LV, Chanda A, Linz JZ (2011) Compartimentalization and molecular traffic in secondary metabolismo: a new understanding of established cellular processes Fungal Genetics and Biology 48(1):35-48.
Santos GHF, Silva EB, Silva BL, Sena KXFR, Lima CSA (2011) Influence of gamma radiation on the antimicrobial activity of crude extracts of Anacardium occidentale $\mathrm{L}$ Anacardiaceae rich in tannins. Brazilian Journal of Pharmacognosy 21(3):444-449.

Santos VHM, Daneluzzi GS, Silva LP, Silva RMG (2015). Evaluation of Allelopathic Potential of Leaf extract of Kielmeyera coriácea on Lactuca sativa L. Bioscience Journal 31(1):259-267.

Sas Institute (2002) User's manual version 9.1. In: (Ed). SAS Institute. Cary: NC.

Silva AA, Silva JF (2007) Tópicos em manejo de plantas daninhas, Viçosa. 367p.

Silva RMG, Saraiva TS, Silva RB, Gonçalves LA, Silva LP (2010) Potencial alelopático de extrato etanólico de Anadenanthera macrocarpa e Astronium graveolens. Bioscience Journal 26(4):632-637.

Spilioti E, Jaakkola M, Tolonen T, Lipponen M, Virtanen V, Chinou I, Kassi E, Karabournioti S, Moutsatsou P, Volti GL (2014) Phenolic acid composition antiatherogenic and anticancer potential of honeys derived from various regions in Greece. PLoS One 9(4):e94860.

Vyvyan JR (2002) Allelochemicals as leads for new herbicides and agrochemicals. Tetrahedron Letters 58(9):1631-1646.

Weber CR, Soares CML, Lopes ABD, Silva TS, Nascimento MS, Ximenes ECPA (2011) Anadenanthera colubrina: um estudo do potencial terapêutico. Revista Brasileira de Farmacologia 92(4):235-244.

Wolny E, Betekhtin A, Rojek M, Braszewska-Zalewska A, Lusinska J, Hasterok R (2018) Germination and the Early Stages of Seedling Development in Brachypodium distachyon. International Journal of Molecular Science 19(10):2916. 